\title{
CZESKI HISTORYK JAROSLAV BIDLO I JEGO UDZIAŁ W RUCHU NEOSŁOWIAŃSKIM PRZED I WOJNA ŚWIATOWĄ ${ }^{1}$
}

\section{Marek Ďurčanský}

http://orcid.org/0000-0001-6950-2082

Uniwersytet Karola w Pradze (Czechy)

\author{
ABSTRACT \\ CZECH HISTORIAN JAROSLAV BIDLO AND HIS INVOLVEMENT \\ IN THE NEO-SLAV MOVEMENT BEFORE WORLD WAR I
}

The Czech historian Jaroslav Bidlo (1868-1937) was one of the few Austro-Hungarian scholars who possessed vast and critical knowledge in the field of history of Slavic nations. His knowledge was based on his own experience gathered in Polish and Russian academic circles before World War I. As a professor of the Czech Charles-Ferdinand University he was involved in the so-called Neo-Slav movement, which culminated in the "Slavic Congress" in Prague in July 1908, and in the edition of a collective monograph about the Slavic nations (Slovanstvo, Prague 1912). Bidlo used these opportunities to create his own synthetic concept of Slavic history, which he later successfully developed during the interwar period.

Keywords: Neo-Slav movement, history of Slavic studies, Jaroslav Bidlo, Prague.

Słowa kluczowe: ruch neosłowiański, historia słowianoznawstwa, Jaroslav Bidlo, Praga.

\section{WSTĘP}

W dziejach narodów słowiańskich w XIX i XX wieku pojawiała się powtórnie z różną intensywnością oraz w różnych kontekstach idea wzajemności słowiańskiej.

Artykuł stanowi część realizacji projektu badawczego „Jaroslav Bidlo a Milada Paulová: zakladatelské osobnosti historické slavistiky v kontextu vývoje české vědy", dofinansowanego przez Agencję Grantową Republiki Czeskiej (grant nr 18-20451S).

Adres do korespondencji: marek.durcansky@ruk.cuni.cz 
Czasami idealistycznie oceniana i entuzjastycznie przyjmowana przez społeczeństwo, czasami wykorzystywana do celów politycznych czy odrzucana jako niebezpieczna ideologia przetrwała przez wiele generacji i wraca w niespodziewanych metamorfozach do dzisiaj. W historiografii czeskiej poświęcono jej w przeszłości już wiele miejsca, pewne wątki zostały jednak poruszone tylko częściowo.

Z czeskiego punktu widzenia jedną z najciekawszych odmian idei wzajemności narodów słowiańskich stanowi tak zwany neoslawizm. W nim powróciła po raz trzeci od pierwszej połowy XIX wieku kwestia stosunków polsko-rosyjskich, które wcześniej zaważyły na odniesieniu publiczności czeskiej do idei słowiańskiej wzajemności. Polskie powstania z lat 1831 i 1864 podzieliły społeczeństwo czeskie, zmuszone patrzeć na stosunki narodów słowiańskich bardziej krytycznie ${ }^{2}$. Warto więc spróbować spojrzeć na neoslawizm z punktu widzenia jednego z niewielu czeskich uczonych, którzy na początku XX wieku dysponowali nieprzeciętną wiedzą w zakresie historycznych oraz współczesnych stosunków między narodami słowiańskimi.

Praski zjazd „neosłowiański” (1908) stanowił niewątpliwie jedno z najważniejszych wydarzeń w ramach ruchu neosłowiańskiego. Cztery lata później, kiedy od dłuższego czasu zaczęły pojawiać się zasadnicze tarcia wewnątrz tego ruchu, uniemożliwiające rzeczywistą współpracę kulturalną i gospodarczą wszystkich (albo przynajmniej większości) narodów słowiańskich, wydano w Pradze obszerną publikację z tegoż zjazdu. Książka licząca prawie 800 stron została zatytułowana Slovanstvo. Obraz jeho minulosti a př́tomnosti [Słowiańszczyzna. Obraz jej przeszłości i teraźniejszości] $]^{3}$. Z grona 15 autorów wymieniono we wstępie autorstwa czołowego polityka młodoczeskiego Karola Kramářa dwóch redaktorów: etnografa Jiříego Polívkę oraz historyka Jaroslava Bidlo ${ }^{4}$. Postać drugiego z wymienionych uczonych ${ }^{5}$

2 K. Krejčí, První krise českého slovanství. Vliv polského povstání listopadového na české národní obrození, „Slovanský přehled” 1928, t. 20, s. 13-22, 108-122, 177-201, 249-272; idem, „Poláci v Čechách v době povstáni listopadového a ,velké emigrace”, „Slovanský přehled” 1930, t. 22, s. 504 509, 583-598, 670-678, 721-741; V. Žáč ek, Ohlas polského povstání 1863 v Čechách, Praha 1935.

3 Slovanstvo. Obraz jeho minulosti a prítomnosti, red. J. Bidlo, J. Polívka, Praha 1912. Książka została wydana w znanym wydawnictwie Jana Laichtera, które skupiało się na literaturze naukowej.

4 K. Kramář, Úvodem [w:] Slovanstvo..., s. XV; zob. także Doslov [w:] Slovanstvo..., s. 748.

5 Czeski historyk Jaroslav Bidlo (1868-1937) był wychowankiem Czeskiego Uniwersytetu Karola-Ferdynanda w Pradze oraz Uniwersytetu Jagiellońskiego (pobyt w Krakowie w roku akademickim 1892/93). Doktoryzował się w 1894 r., a w kolejnych latach nauczał w szkołach średnich i pracował naukowo. W 1900 r. habilitował się w zakresie historii powszechnej, w 1905 r. cesarz zatwierdził jego nominację na profesora nadzwyczajnego i w $1911 \mathrm{r}$. na profesora zwyczajnego. W okresie międzywojennym należał do czołowych postaci historiografii czeskiej, także na polu organizacyjnym w Republice Czechosłowackiej (członek Czeskiej Akademii Nauk i Sztuk Pięknych, Królewskiego Czeskiego Towarzystwa Nauk, Instytutu Słowiańskiego w Pradze) i na polu międzynarodowym (członek zagraniczny zwyczajny Polskiej Akademii Umiejętności, Towarzystwa Naukowego im. Szewczenki, prezes Związku Towarzystw Historycznych Europy Wschodniej itp.). Jego zainteresowania badawcze oprócz historii narodów słowiańskich skupiały się także na całościowym ujęciu dziejów Jednoty Braci Czeskich na uchodźstwie polskim, której poświęcił swoje największe dzieło. Skupiam się na podstawowych informacjach, ponieważ niedawno opracowano tematykę dotyczącą Bidlo i jego stosunku do historiografii polskiej w osobnym tekście, który zawiera także odniesienia do odpowiedniej literatury przedmiotu. Zob. M. Ďurčanský, Historyk Jaroslav Bidlo (1868-1837) - tącznik między krakowska szkoła historyczna i czeska szkoła historyczna Jaroslava Golla (1846-1929) [w:] Krakowska szkoła historyczna a Polskie 
stanowiła niewątpliwie dobry wybór jako redaktora. Jako profesor zwyczajny historii narodów słowiańskich i Półwyspu Bałkańskiego reprezentował C.K. Czeski Uniwersytet Karola-Ferdynanda (jeden z symboli emancypacji kulturalnej narodu czeskiego) oraz „historyczną szkołę czeską”, której nie brakowało ambicji opartych nie tylko o ważne wydawnictwa, lecz także o powiększające się szeregi zdolnych absolwentów. Do wspomnianej pracy zbiorowej Bidlo napisał dwa podstawowe teksty: obszerny szkic historii narodów słowiańskich i przegląd ich życia religijnego w przeszłości ${ }^{6}$. Co jednak spowodowało, iż nazwiska Bidlo (w przeciwieństwie do J. Polívki) zupełnie brakuje w szczegółowych opisach posiedzeń Zjazdu Słowiańskiego z 1908 roku$^{7}$, mimo że cztery lata później uczony odgrywał decydującą rolę w przygotowaniu pomnikowego wydawnictwa? Niniejszy artykuł jest właśnie próbą odpowiedzi na to pytanie.

\section{POCZĄTKI RUCHU NEOSŁOWIAŃSKIEGO}

Ruch neosłowiański ${ }^{8}$ był reakcją części elit intelektualnych i politycznych narodów słowiańskich na zmiany w sytuacji geopolitycznej pierwszej dekady XX wieku, przede wszystkim reform w Rosji i Królestwie Polskim po 1905 roku, wielkoniemieckiego Drang nach Osten oraz wzrostu liczby posłów słowiańskiego pochodzenia w wiedeńskiej Radzie Państwa po wprowadzeniu równego i powszechnego prawa wyborczego w 1907 roku. Zwolennicy ruchu neosłowiańskiego próbowali uniezależnić idee wzajemności słowiańskiej od tradycyjnego panslawizmu rosyjskiego, którego tło stanowiły ambicje imperialne caratu. Teoretycznie na pierwszym planie idei neosłowiańskiej znajdowała się równość pojedynczych narodów, wzajemny

Towarzystwo Historyczne. Studia historiograficzne, red. P. Biliński, P. Plichta, Warszawa-Kraków 2017, s. 47-59.

6 J. Bidlo, Historický vývoj Slovanstva [w:] Slovanstvo..., s. 3-131; Náboženské a církevní poměry národi̊ slovanských [w:] Slovanstvo..., s. 344-388.

7 Jednáni I. prípravného slovanského sjezdu v Praze 1908, Praha 1910. Protokoły z posiedzień zjazdu zredagował jeden z członków delegacji czeskiej, dziennikarz Bohdan Pavlů (Slovanstvo..., s. 70).

8 Na temat ruchu neosłowiańskiego ostatnio: F. Hadler, ,....nevertheless, a great theatrical exhibition of Slav Solidarity". Der Prager Slawen-Kongress von 1908 als Hauptaktion des Neoslawismus [w:] Approaches to Slavic Unity. Austro-Slavism, Pan-Slavism, Neo-Slavism and Solidarity Among the Slavs Today, red. K.A. Makowski, F. Hadler, Poznań 2013, s. 131-151; R. Vlček, Ruský panslavismus realita a fikce, Praha 2002, s. 218-237. Ze starszej literatury zob. A. Giza, Neoslawizm i Polacy 19061910, Szczecin 1984; R. Jaworski, Die polnische und die tschechische Variante des Neoslawismus [w:] Polen und die böhmischen Länder im 19. und 20. Jahrhundert. Politik und Gesellschaft im Vergleich. Vorträge der Tagung des Collegium Carolinum in Bad Wiessee vom 15. bis 17. November 1991, hrsg. P. Heumos, München 1997, s. 43-55; R. Vlč ek, Nacionalismus, panslavismus a neoslavismus - pokusy o řešení krize ruského impéria na přelomu 19. a 20. století?, „Slovanský přehled” 1994, t. 80, s. 1-17; P. Vyšný, Neo-Slavism and the Czechs 1898-1914, Cambridge [et al.] 1977; H. B atow ski, Neoslawizm a stosunki polsko-rosyjskie i polsko-czeskie (1908-1914) [w:] Z polskich studiów slawistycznych, seria 3. Historia. Prace na VI Międzynarodowy Kongres Slawistów w Pradze 1968, Warszawa 1968, s. 236-245. 
szacunek i współpraca; odwoływano się zwłaszcza do prekursorów tych idei - Mickiewicza, Krasińskiego, Lubomirskiego, Palackiego, Šafař́ka i innych ${ }^{9}$. Zastosowanie tych zasad w praktyce stanowiło oczywiście rzecz bardzo trudną.

Z czołowych polityków czeskich najbardziej z ruchem neosłowiańskim związał się przedstawiciel partii młodoczeskiej Karel Kramár. Właśnie on najżyczliwiej zareagował na list profesora Wydziału Prawa Uniwersytetu w Odessie Aleksandra Brodzenki nawołujący do zwołania wszechsłowiańskiego zjazdu. Kramář połączył tę inicjatywę z planami czeskich kół dziennikarskich na upamiętnienie 60-lecia Zjazdu Słowiańskiego w Pradze z 1848 roku. W maju 1908 roku wyjechał wspólnie z dwoma słowiańskimi posłami wiedeńskiej Rady Państwa, Słoweńcem Ivanem Hribarem i Rusinem Mykołą Hlibowickim (zwolennikiem orientacji prorosyjskiej), do Petersburga i Warszawy. Chodziło do pewnego stopnia o oficjalną wizytę, ponieważ Kramáŕ przed wyjazdem konsultował swoje zamiary z austriackim ministrem spraw zagranicznych Aloisem Lexą von Aehrenthal. Społeczeństwo czeskie z entuzjazmem powitało powrót Kramárá, który wyniki swojej wizyty zaprezentował jako przezwyciężenie przeszkód wynikających ze sporu polsko-rosyjskiego - przynajmniej do tego stopnia, że obie strony zgodziły się na uczestnictwo w zjeździe, który wkrótce miał się odbyć w czeskiej stolicy ${ }^{10}$.

Entuzjazmu społeczeństwa oraz części słowiańskiej prasy nie podzielał czołowy czeski znawca problematyki narodów słowiańskich, wydawca cenionego czasopisma „Slovanský přehled” Adolf Černý. Na łamach swojego periodyku opowiadał z dużą dozą sceptycyzmu o zmianie nastawienia niektórych, niechętnych do tej pory Polakom, polityków rosyjskich (Władimir Aleksiejewicz Bobrinski) i ubolewał nad decyzją polityków ruskich (ukraińskich) o niebraniu udziału w zjeździe. W końcu jednak starał się znaleźć pozytywne wątki zaplanowanego wydarzenia:

A więc: myślę, iż tymczasem brak powodu do entuzjazmu - ale też do zupełnej negacji. W Rosji wypływają na powierzchnię sympatyczne prądy, które trzeba wykorzystać w interesie sprawy nam wszystkich drogiej, która jest kwestią życiową nas wszystkich. Dlatego życzę powodzenia przygotowywanej naradzie praskiej reprezentantów słowiańskich. Jeżeli wyzwoli się z mgły jałowego i natchnionego zapału, oraz jeżeli uda się jej stanąć na konkretnym gruncie i opracować naprawdę realny i cenny punkt wyjścia dla przyszłego zjazdu słowiańskiego - będzie to korzyść dla sprawy słowiańskiej ${ }^{11}$.

9 Wystąpienie pożegnalne Mariana Zdziechowskiego na Przygotowawczym Zjeździe Słowiańskim w Pradze w 1908 r. Jednání I. př́pravného slovanského sjezdu v Praze 1908, s. 69. Na temat zaangażowania się Zdziechowskiego na praskim zjeździe: Z. Opacki, W kręgu Polski, Rosji i Słowiańszczyzny. Myśl i działalność społeczno-polityczna Mariana Zdziechowskiego do 1914 r., Gdańsk 1996, s. 218-219.

10 M. Lustigová, Karel Kramár. První československý premiér, Praha 2007, s. 107-110; V. Doubek, T. G. Masaryk a česká slovanská politika, Praha 1999, s. 120-123; R. Vlč ek, op. cit., s. 13-14.

${ }^{11}$ „Nuže: myslím, že zatím není příčiny k nadšení - ale také ne k naprosté negaci. V Rusku vyplývají na povrch proudy sympatické, jichž je třeba užíti v zájmu věci všem nám drahé, která jest životní otázkou nás všech. Proto přeji zdaru chystané pražské poradě slovanských zástupců. Vybaví-li se z mlhy planého a nadšeného horování a podaří-li se jí stanouti na konkrétní půdě a vypracovati opravdu reálný a cenný podklad pro příští slovanský sjezd - bude to zisk věci slovanské [...]”. A. Černý, Po slovanských dnech v Petrohradě a Varšavě, „Slovanský přehled” 1908, t. 10, s. 446. Tłumaczenie cytatów z czeskiego M.Ď. Pragnę podziękować za pomoc językową dr. Robertowi Tomczakowi z Wydziału Historycznego UAM w Poznaniu. 


\section{ZJAZD SŁOWIAŃSKI W PRADZE W 1908 ROKU}

I Przygotowawczy Zjazd Słowiański odbył się w Pradze w dniach 12-17 lipca 1908 roku. Chociaż uczestnicy w zasadzie starali się unikać spraw drażliwych i występować kompromisowo, pewne sytuacje konfliktowe i tak się pojawiły. Na przykład w ciągu trzeciego dnia delegat polski Michał Grek skomentował toast wzniesiony przez hrabiego Bobrinskiego za zdrowie tych, którzy przyjechać nie mogli albo nie chcieli. Sprawę zrozumiano jako inwektywę skierowaną w stronę Rusinów galicyjskich. Ten sam delegat polski zareagował także na wypowiedź rosyjskiego dziennikarza Dymitra Werguna dotyczącą stosunków polsko-ruskich w Galicji ${ }^{12}$.

Ponieważ przebieg zjazdu został już dokładnie przeanalizowany z różnych punktów widzenia ${ }^{13}$, skupiam się $\mathrm{w}$ tym miejscu tylko na krótkim podsumowaniu ${ }^{14}$, żeby pokazać, jakie miejsce zajmowały w ramach zjazdu sprawy naukowe i gdzie pojawiła się idea publikacji o Słowiańszczyźnie. Pierwszy dzień poświęcono uroczystemu powitaniu w ratuszu Starego Miasta Praskiego, w ciągu drugiego dnia wybrano zarząd, uzgodniono sprawy proceduralne oraz odbywano obrady na temat powszechnej wystawy słowiańskiej oraz turystyki. Na trzeci dzień dyskutowano ponownie o przygotowaniu wystawy, dalej omawiano kwestię współpracy na polu oświaty i medycyny (Związek Lekarzy Słowiańskich), poruszono ponownie problematykę turystyki oraz ruchu sokolego. Możliwości współpracy na polu nauki (konferencje „słowiańskie" w poszczególnych dziedzinach naukowych, peregrynacja akademicka, języki publikacji naukowych) naszkicował rosyjski lekarz Władimir Biechtieriew. Sprawę tę, zgodnie z wnioskiem Polívki, zlecono samodzielnej komisji, w której skład weszli uczeni spośród delegatów zjazdu ${ }^{15}$. Czwarty dzień obrad zajęły dyskusje na temat współdziałania na polu żurnalistyki oraz gospodarki, zwłaszcza idea wspólnego Banku Słowiańskiego - instytucji, która powinna była stanowić przeciwwagę dla kapitatu niemieckiego, oraz sprawy szkolnictwa i muzealnictwa rolniczego (w tym punkcie przecinały się zainteresowania oświatowe i gospodarcze). Wieczorem czwartego dnia obrad odbył się bankiet z licznymi toastami. Piątego dnia dyskutowano ponownie o ruchu sokolim oraz księgarstwie słowiańskim. Delegaci wygłosili podziękowania, wybrali kandydatów do komitetu wykonawczego z siedzibą w Pradze i dyskutowali o kształcie komitetów dla poszczególnych spraw.

Niemalże na sam koniec obrad rosyjski delegat M.W. Krasowski podsumował, iż jego delegacja zebrała dla upamiętnienia pobytu w Pradze 2000 koron:

[...] na wydanie książki dla szerokich warstw ludowych, w której zostałyby opisane wszystkie kraje i narody słowiańskie, ażeby szerzyć znajomość słowiańskich krajów oraz słowiańskiej

12 Jednáni I. prípravného slovanského sjezdu v Praze 1908, s. 21-23.

13 A. Giza, op. cit., s. 101-140; P. Vyšný, op. cit., s. 91-124. Ze współczesnego punktu widzienia stanowi bardzo ważny głos w debacie o wynikach zjazdu krytycznie nastawiony: A. Černý, Slovanské sjezdy r. 1908, „Slovanský přehled” 1909, t. 11, s. 7-15, 61-69.

14 Na podstawie: Jednání I. prípravného slovanského sjezdu v Praze 1908.

15 Ibidem, s. 30-32, 39-40. 
Pragi. Sumę oddajemy dr. Kramářowi, żeby załatwił wszystkie kolejne potrzebne sprawy w tym kierunku ${ }^{16}$.

Polski delegat Michał Chyliński w nawiązaniu do niego stwierdził, że delegacja polska zebrała dla tegoż zamiaru kolejnych 1600 koron $^{17}$. Wykonanie tego planu zlecono Narodowej Radzie Czeskiej, której przedstawiciele szybko zdecydowali o formie publikacji. Stwierdzono, że bardziej niż broszura popularyzatorska potrzebne jest:

[...] duże dzieło o Słowiańszczyźnie, które w postaci obszernych i dokładnych monografii zaprezentowałoby nam obraz tego wszystkiego, co nazywamy Słowiańszczyzną, jej dziejów politycznych, religijnych, jej rozwoju kulturalnego oraz jej dążeń duchowych i materialnych ${ }^{18}$.

Kiedy Kramár̆ trzy lata później pisał wstęp do publikacji, wynikłe opóźnienie tłumaczył kłopotami z zebraniem tekstów o tematyce gospodarczej ${ }^{19}$.

\section{MONOGRAFIA SLOVANSTVO I PRACA REDAKCYJNA JAROSLAVA BIDLO}

Książka w pięknej secesyjnej oprawie prezentowała się jako zwarta monografia, choć udział poszczególnych autorów był jednak dosyć różnorodny. Najobszerniejsze teksty stanowiły rozdziały napisane przez profesorów czeskiego uniwersytetu: o ustroju prawnym narodów słowiańskich pióra Karola Kadleca (209 s.), o historii Słowiańszczyzny Jaroslava Bidlo (129 s.) oraz o literaturze słowiańskiej Jana Máchala (97 s.). Bidlo oprócz tego napisał jeszcze rozdział o życiu religijnym Słowian (45 s.). Kolejne teksty zostały poświęcone sztuce pięknej, muzyce, organizacji szkolnictwa, dziennikarstwu, statystyce, ruchowi sokolemu oraz turystyce ${ }^{20}$.

Udział Jaroslava Bidlo w przygotowaniu Slovanstva jest niewątpliwym dowodem jego zaangażowania się w ruch neosłowiański. Wydaje się jednak prawdopodobne, że jego działalność na rzecz tego ruchu została określona przede wszystkim za sprawą przygotowania wymienionej monografii. Korespondencja Bidlo z lat 1908-1912 zawiera zadziwiająco mało informacji na ten temat ${ }^{21}$. Brak także korespondencji ze

16 „na vydání knihy pro široké vrstvy lidové, v níž byly by popsány všechny země a národy slovanské, aby se šírila znalost slovanských krajin i slovanské Prahy. Obnos odevzdáváme dr. Kramářovi, aby vše další v tom směru zařídil”.

17 Jednáni I. prípravného slovanského sjezdu v Praze 1908, s. 69.

18 ,veliké dílo o Slovanstvu, které by obšírnými a důkladnými monografiemi podalo nám obraz všeho toho, co nazýváme Slovanstvem, jeho dějin politických, náboženských, jeho rozvoje kulturního i jeho snah duševních i hmotných".

19 K. Kramář, Úvodem [w:] Slovanstvo..., s. VI. Zob. również posłowie, ibidem, s. 747.

20 Niedługi rozdział dotyczący turystyki napisało grono siedmiu autorów. Problematykę turystyki polskiej poruszył kustosz praskiej biblioteki uniwersyteckiej Bořivoj Prusík.

21 Mowa o korespondencji z jego kolegami historykami Jaroslavem Gollem, Václavem Novotnym, Josefem Šustą, Bohumilem Navrátilem i z rodzicami. Z korespondencji z Navrátilem wynika, iż Bidlo w latach 1908-1912 bardzo intensywnie zajmował się przygotowywaniem edycji dotyczącej Braci Czeskich, którą wydano w latach 1915-1923. Pracę nad monografią o Słowiańszczyźnie 
współautorami Slovanstva (zachowane listy obejmują inne lata); wyjątek stanowi tylko nieliczna korespondencja ze statystykiem Antonínem Boháčem² ${ }^{22}$ Niewykluczone, że potencjalnie kompromitujące listy, które mogły być na początku I wojny światowej postrzegane jako zdradzieckie, Bidlo zniszczył. Warto pamiętać, że prezesa praskiego zjazdu neosłowiańskiego Karola Kramáŕa skazano podczas wojny na śmierć (choć wyroku w końcu nie wykonano) i wspólnie z nim więziono także kolejnych delegatów czeskich, prezesa stronnictwa narodowo-socjalistycznego Václava Klofáča oraz ekonomistę Jaroslava Preissa.

Na szczęście zachowała się autobiografia Bidlo ${ }^{23}$, w której, przynajmniej częściowo, autor wyjaśnia swoje zaangażowanie w ruch neosłowiański. Według tego świadectwa brał on udział w pracach przygotowawczych zjazdu od samego początku ${ }^{24}$. Także decyzja o napisaniu rozdziału o historii Słowiańszczyzny zapadła prawdopodobnie bardzo szybko, ponieważ powstający tekst wykorzystywał do swoich wykładów uniwersyteckich ${ }^{25}$.

Z dzisiejszego punktu widzenia nie ulega wątpliwości, iż obowiązki Bidlo dotyczące Slovanstva bardzo przyczyniły się do powstania jego pierwszej koncepcji syntetycznego ujęcia historii narodów słowiańskich oraz uzasadnienia samego przedsięwzięcia. Jeszcze przed wydaniem dzieła zbiorowego Bidlo ogłosił na łamach „Českiego časopisu historickiego" artykuł o historii Słowiańszczyzny jako całości²6, w którym naszkicował ówczesny stan historycznej slawistyki. Według Bidlo została

opisywał: „Robię teraz popularną historię Słowiańszczyzny, która powinna okazać się nakładem pewnego funduszu, zebranego w zeszłym roku przez Polaków. Dlatego musiałem skrócić swoje wakacje”. „Dělám ted' populární historii Slovanů, která má vyjít nák1[adem] jistého fondu, sebraného loni Poláky. Proto jsem musel zkrátit svoje prázdniny”. Moravský zemský archiv, Bohumil Navrátil, sygn. G 57, kart. 1, J. Bidlo do B. Navrátila, 2 IX 1909, Praga. Z zagranicznych korespondentów można było spodziewać się wymiany myśli na temat ruchu nowosłowiańskiego w przypadku redaktora „Świata Słowiańskiego” Feliksa Konecznego, z którym Bidlo był w sporadycznym kontakcie od czasów studiów w Krakowie (1892/93) do połowy lat 30. W ich korespondencji jednak znajduje się luka w latach 1902-1914. Zob. Korespondencja Feliksa Konecznego z Jaroslavem Bidlo, wyd. P. Biliński, M. Ďurčanský, „Biuletyn Biblioteki Jagiellońskiej” 2016, t. 66, s. 45-68.

22 Masarykův ústav a Archiv Akademie věd ČR, zesp. Jaroslav Bidlo, nr. j. 78. Korespondencja dotyczy złożenia oryginalnego tekstu Boháča do redakcji wydawnictwa w marcu 1910 r. oraz drugiej korekty (kartka pocztowa bez daty).

23 Istnieją cztery obszerniejsze teksty autobiograficzne Bidlo. Najstarszy pisał podczas wojny pod wrażeniem czasowego zerwania stosunków z Jaroslawem Gollem (zob. Jaroslav Bidlo. Moje styky s Gollem, red. M. Ďurčanský [w:] Jaroslav Goll a jeho žáci, red. B. Jiroušek, J. Blüm1, D. Blümová, České Budějovice 2005, s. 657-681). Kolejne trzy teksty zostały napisane w latach 20. XX w. w związku ze zbliżającymi się obchodami jego 60. urodzin. Różnią się podejściem i tylko jeden z nich obejmuje cały okres życiowy Bidlo do końca lat 20. W tej autobiografii znajduje się także ustęp o ruchu neosłowiańskim. Zob. Jaroslav Bidlo - Milada Paulová. Střet generaci? Paméti a vzájemná korespondence zakladatelì české byzantologie a slovanských studií, red. D. Brádlerová, J. Hálek, Praha 2014, s. 64.

${ }^{24}$ Jaroslav Bidlo - Milada Paulová..., s. 64. Warto zauważyć, iż niewielka liczba uczonych w komitecie praskiego zjazdu zadziwiała już A. Černego, Slovanské sjezdy..., s. 11.

${ }_{25}$ W roku akademickim 1909/10: Přehledné dějiny národů slovanských (Dzieje narodów słowiańskich w zarysie). W jego działalności pedagogicznej, wykładu pod tym tytułem, poźniej już nigdy nie powtórzono.

26 J. Bidlo, O historii Slovanstva jako celku, „Český časopis historický” 1911, t. 17, s. 143-151. 
ona zdominowana przez ,starożytności słowiańskie” - badacze we współpracy z archeologami i antropologami próbowali przede wszystkim zrekonstruować wspólne pradzieje narodów słowiańskich. W dłuższej skali czasowej tylko Oswald Balzer zaprezentował na III Powszechnym Zjeździe Historyków Polskich w Krakowie koncepcję porównawczych dziejów prawa narodów słowiańskich. Bidlo obserwował także instytucjonalizację historycznej slawistyki w formie samodzielnych profesur oraz seminariów historii Europy Wschodniej na uniwersytetach w Niemczech i Austro-Węgrzech:

U nas niedawno praktyczne zainteresowanie dzisiejszej doby, odnowione usiłowanie kulturalnego i gospodarczego współdziałania narodów słowiańskich, ukształtowania jakiegoś praktycznego wspólnego programu, ruch, nazywany neosłowiańskim - wywołały potrzebę głębszego, naukowego wglądu do realnej przeszłości narodów słowiańskich, żeby znaleźć gwarancje oraz przesłanki dla powodzenia odnawianej solidarności. [...] Można tudzież oczekiwać, iż odnowione usiłowania o praktyczne zastosowanie wzajemności słowiańskiej, ugruntowanej znaczącym postępem na polu gospodarki i oświaty, który Słowianie osiągnęli w ciągu ostatniego ćwierczwiecza, w związku z wyżej wymienionymi odczuwanymi potrzebami naukowymi uruchomią ponownie dążenie do ukształtowania naukowego obrazu całej przeszłości słowiańskiej, ewentualnie też do zbudowania nowej filozofii dziejów Słowiańszczyzny, opierających się na bezpiecznych wynikach fachowych badań ${ }^{27}$.

Chociaż Bidlo odczuwał bieżące zainteresowanie historią Słowiańszczyzny, odmawiał racji stanowisku, które postrzegało narody słowiańskie jako organiczną historyczną całość (reprezentowanym m.in. przez rosyjskiego slawistę Antona Budiłowicza). Zwracał uwagę na bardzo bliskie stosunki niektórych etnicznych grup słowiańskich z ich sąsiadami - Niemcami, Turkami, Węgrami, Rumunami i innymi. W ten sposób zbliżał się już do swojej późniejszej teorii, według której Słowianie należą do dwóch różnych kultur (cywilizacji): grecko-słowiańskiej oraz romańsko-germańskiej. Zasadniczą rolę w takim rozdzieleniu odgrywa religia ${ }^{28}$, z jednej strony

27 „U nás nedávno praktický zájem př́tomné doby, obnovený pokus o kulturní a hospodářskou součinnost slovanských národů, o vytvoření nějakého praktického společného programu, hnutí, nazývané novoslovanstvím - vyvolaly potřebu hlubšího, vědeckého nahlédnutí do reální minulosti slovanských národů, aby se vyhledaly záruky nebo předpoklady pro zdar obnovované solidarity. [...] Lze tudíž očekávati, že obnovené pokusy o praktické provádění slovanské vzájemnosti, založené na značném hospodářském a osvětovém pokroku, kterého dosáhli Slované za poslední čtvrtstoletí, v souvislosti $\mathrm{s}$ cítěnými potřebami vědeckými shora dotčenými uvedou znovu do proudu snahu o vytvoření vědeckého obrazu celkové minulosti slovanské, po př́padě i po zbudování nové filosofie dějin slovanských, opírajících se o bezpečnější výsledky odborného studia”. Ibidem, s. 146-147.

${ }_{28} \mathrm{Z}$ dychotomii prawosławia i zachodnich prądów chrześcjaństwa wyciągał Bidlo także praktyczne wnioski. Można przytoczyć cytat z jego prywatnego listu do kolegi historyka Josefa Šusty z początku lat 20., kiedy Šusta w roli ministra oświaty zajmował się problematyką pomocy inteligencji rosyjskiej na emigracji: „Jeżeli zwraca się uwagę na to, iż Serbowie i Bułgarzy robią na rzecz Rosjan więcej niż my, nawet to nie jest powodem prawdziwym, ponieważ Rosjanie zawsze interesowali się tylko prawosławnymi narodami słowiańskimi, a Serbom i Bułgarom dopomogli w uzyskaniu swobody, natomiast nam pomagali psuć nawet te artykuły fundamentalne. Gdyby Rosja się utrzymała, uniemożliwiłaby rozbicie Austro-Węgier”. („Poukazuje-li se na to, že Srbové a Bulhaři pro Rusy dělají mnohem více nežli my, ani to není důvod reálný, poněvadž Rusové vždycky se zajímali jen o pravoslavné slovanské národy a Srbům a Bulharům dopomohli k svobodě, kdežto nám pomáhali mařit i ty fundamentálky! Kdyby se Rusko bylo udrželo, bylo by zamezilo rozbití Rakousko-Uherska"). Fundamentalne artykuły przedstawiały nieudaną 
prawosławie, z drugiej zaś katolicyzm z późniejszymi konfesjami protestanckimi. W ramach takiego rozdzielenia Słowianie Zachodni (Polacy, Czesi, Słowacy, Serbowie Łużyccy) razem z Chorwatami oraz Słoweńcami należeli do cywilizacji romańsko-germańskiej ${ }^{29}$. W każdym razie nie odmawiał racji próbom syntetycznego spojrzenia na dzieje narodów słowiańskich, podkreślał jednak, opierając się na teoretycznych rozważaniach Ernsta Bernheima, konieczność komparatystycznego podejścia szukającego oprócz podobieństw także różnic ${ }^{30}$.

W momencie ogłoszenia monografii Slovanstvo, albo niewiele wcześniej, Bidlo spróbował na łamach dziennika „Národní listy”31 zaznajomić szeroką publiczność z treścią książki oraz okolicznościami jej powstania. Zaprezentował ją w zasadzie jako jedyny sprawdzony pozytywny wynik praskiego zjazdu - w tym zgadzał się także z o wiele późniejszymi opiniami ${ }^{32}$. Starał się też bronić samej idei zwołania zjazdu i jego przebiegu: podkreślał, że chodziło o zjazd przygotowawczy i tym razem spodziewano się zasadniczych wyników dopiero od kolejnych zjazdów, które mogłyby wykorzystać uzyskane doświadczenia oraz wyniki prac poszczególnych komisji. Samą publikację charakteryzował jako ściśle naukową, liczącą jednak na szerokie grono czytelników:

Uczestnicy zjazdu praskiego życzyli sobie, żeby dokładniejsze i bardziej szczegółowe wiadomości o Słowiańszczyznie nie zostawały w przyszłości tylko jakimś przywilejem kilku wybrańców naukowych i politycznych, lecz żeby ci, którzy wiedzą więcej, puścili swoje wiadomości w szeroki obieg popularnego czytelnictwa. [...] Duch, który przenika całym wydawnictwem, to duch nauki. Ideał nauki stanowi poznanie prawdy. Nauka oczywiście może się mylić. Ale jak wszędzie w życiu, tak szczególnie w nauce obowiązuje reguła: uczymy się na błędach. Dyskusja naukowa wiedzie do poznania rzeczywistej prawdy i jest w ten sposób osiągalna. Niniejsze dzieło nie stanowi żadnej dogmatyki, lecz na pewno przedstawia stanowczy postęp na polu słowianoznawstwa ${ }^{33}$.

Niewątpliwie, można stwierdzić, że Bidlo uważał sam siebie na pierwszym miejscu jako uczonego, który powinien traktować problemy krytycznie, a dopiero na drugim jako słowianofila. Tego rodzaju stanowisko można znaleźć często w jego korespondencji ${ }^{34}$ i explicite także w posłowiu Slovanstva:

próbę politycznego równouprawnienia Czechów w 1871 r. Národní archiv, zesp. Josef Šusta, kart. 2, n. j. 16, J. Bidlo do J. Šusty, Praga, 20 XII 1920.

29 J. Macůrek, Dějepisectví evropského východu, Praha 1946, s. 24-25.

30 J. Bidlo, O historii Slovanstva jako celku..., s. 147, 151.

31 Idem, Positivni výsledek pražského sjezdu novoslovanského r. 1908, „Národní listy”, 31 XII 1911, nr 360, příloha „Z kulturního života”, s. 1 .

32 P. Vyšný, op. cit., s. 121.

33 „Účastníci sjezdu pražského práli si, aby důkladnější a podrobnější vědomosti o Slovanstvu nezůstávaly napříště jen jakýmsi privilegiem několika vyvolenců vědeckých i politických, nýbrž aby ti, kdož vědí více, pustili vědomosti své v široký oběh populárního čtenářstva. [...] Duch, který celý spis proniká, jest duch vědy. Ideálem vědy jest poznání pravdy. Věda ovšem se může mýliti. Ale jako všude v životě, tak zejména ve vědě platí pravidlo: chybami se učíme. Vědecká diskuse vede ku poznání pravdy skutečné a takto je dosažitelná. Spis př́itomný není žádnou dogmatikou, ale jest zajisté rozhodným pokrokem ve slovanovědě".

${ }^{34}$ Zob. np. Korespondencja Władystawa Semkowicza i Jaroslava Bidlo. Kartka z historii stosunków naukowych polsko-czeskich w okresie międzywojennym, oprac. M. Ďurčanský, „Krakowski Rocznik Archiwalny" 2012, t. 18, s. 148, 152. 
Slawiści czescy należą do najzachodniejszego narodu słowiańskiego, który zawsze najbardziej narażony był na atak, oni są bardziej związani i pociągani do słowiańskiego entuzjazmu dla kwestii wszechsłowiańskich. Jednak wąski ich stosunek do trzeźwej nauki zachodniej kieruje ich kroki, żeby nie zabłądzili na manowcach fantazii i uprzedzeńn ${ }^{35}$.

\section{RECEPCJA MONOGRAFII W ŚRODOWISKACH CZESKICH}

Recenzje Slovanstva pojawiły się w czasopismach różnego rodzaju. Ze względu na rozległość i temat uważano rozdział napisany przez Bidlo za jeden z najważniejszych w publikacji. Na łamach czasopisma „Nová doba” sympatyzującego z kierunkiem politycznym Masaryka recenzent stwierdził, że w tekście bardzo dobrze opisano najstarsze dzieje narodów słowiańskich, w odróżnieniu od najnowszych politycznych dziejów narodu czeskiego, które w ujęciu Bidlo „zaledwie wywołają zgodę"36. Recenzent pozytywnie oceniał charakterystykę neosłowiaństwa i jego szybkiego upadku, który na zewnątrz wyjaśniono aneksją Bośni i Hercegowiny ze strony Austro-Węgier, Bidlo jednak dostrzegał głębsze przyczyny niepowodzenia brak prawdziwego demokratyzmu we wzajemnych relacjach, które warto było pielęgnować przede wszystkim na polu świeckim ${ }^{37}$.

Napisanie recenzji dla „Českiego časopisu historickiego” zlecono Janowi Slavíkowi, z którym Bidlo nie był w dobrych stosunkach, w późniejszym czasie można nawet mówić o otwartej wrogości ${ }^{38}$. Pod tym względem recenzja nie wypadła jednak źle - rozdział o dziejach Słowiańszczyzny, oprócz pewnych zastrzeżeń, recenzent ostatecznie ocenił pozytywnie:

W całości jednak fakty dla tego przeglądu, o którym warto stwierdzić, iż Bidlo nie miał tutaj poważnych poprzedników, i którego trudność jest wprawdzie nadzwyczajna, zostały wybrane szczęśliwie i główne nici dziejów słowiańskich splatano bardzo zręcznie ${ }^{39}$.

Jeżeli zastrzeżenia Slavíka koncentrowały się przede wszystkim na koncepcji dziejów Słowiańszczyzny oraz na proporcjach części tekstu poświęconych pojedynczym narodom słowiańskim, Adolf Černý w najdłuższej i jednocześnie najbardziej

35 „Čeští slavisté náležející $\mathrm{k}$ nejzápadnějšímu národu slovanskému, jenž vždycky nejvíce byl vysazen útoku, napojeni a strhováni jsou více, než slavisté kteréhokoli národa slovanského nadšením pro otázky všeslovanské. Ale těsný jejich styk se stř̌́zlivou vědou západní vede kroky jejich, aby nezbloudili na bezcestí fantasií a předsudkư”. Doslov [w:] Slovanstvo..., s. 747.

36 „sotva vzbudí souhlas”.

37 F. Pakosta, [rec.:] Slovanstvo, „Naše doba” 1912, nr 19, s. 699-700. Powiązanie książki z ruchem neosłowiańskim podkreśla także recenzja: -a 1, [rec.:] Slovanstvo, „Věstník českých profesorů”, II 1912, t. 19 , nr 6, s. 183-184.

38 Zob. J. Bouček, Jan Slavík. Př́běh zakázaného historika, Praha 2002, s. 28.

39 „V celku však fakta pro tento přehled, o němž dlužno vyznati, že Bidlo tu neměl vážných předchůdců a jehož obtížnost je zcela mimořádná, jsou vybírána št'astně a hlavní niti dějin slovanských jsou splétány velmi obratně”. J. Slavík [rec.], Slovanstvo, „Český časopis historický” 1912, t. 18, s. 341-344 (cytat na s. 342). 
krytycznej recenzji Slovanstva ${ }^{40}$ skoncentrował się na kwestiach związanych z bieżącym stanem rzeczy. Aczkolwiek wątpił w sam sens publikacji - według opinii Černego byłoby rzeczą bardziej pożyteczną trzymać się oryginalnego pomysłu i wydać oświatową broszurę - tekst Bidlo uważał obok rozdziałów Kadleca oraz Máchala za najbardziej udany. Oceniał również, że nie zostali pominięci Ukraińcy, a nawet Białorusi, dla których w ruchu neosłowiańskim nie było miejsca. Bidlo miał zrozumienie dla ich dążeń narodowych i w swym tekście zadawał politykom rosyjskim pytanie:

Językowe oraz etnograficzne różnice między Wielkorosjanami i Małorusami wprawdzie nie są tak wielkie, żeby nie było możliwe ich pokonać, ale rozwój historyczny oraz zupełnie różne tradycje są powodem tego, iż Małorusi wolą być odrębną indywidualnością narodową. Komu uda się odwrócić ów liczny naród (22 milionów) od tego „nieszczęśliwego” usiłowania? Czy nie stanowi obowiązku poważnych polityków liczyć się z tym jako z niezmiennym faktem i na tym gruncie urządzić swoją działalność zamiast tłumieniem separatyzmu małoruskiego [w rzeczywistości] go wzmacniać i kopać jeszcze głębszą przepaść między obydwoma ruskimi narodowościami? ${ }^{41}$

Z tymi poglądami Bidlo zgadzał się Černý w zupełności, w odróżnieniu od stwierdzenia, że najważniejszą przeszkodą rozwoju ruchu neosłowiańskiego była aneksja Bośni i Hercegowiny. Zdaniem Černego ruch neosłowiański stał się ofiarą własnej niekonsekwencji i nieszczerości, która umożliwiła zamknięcie oczu zwłaszcza nad stosunkiem Rosji do Polaków i Ukraińców ${ }^{42}$. W tym punkcie ustalenia Bidlo na temat niepowodzenia nowosłowian zrozumiał w inny sposób niż recenzent czasopisma „Naše doba”, Ferdinand Pakosta (zob. wyżej). Bardzo krytycznie Černý był nastawiony także do rozdziału o zasadniczej roli kościoła w historii i współczesności narodów słowiańskich, która jego zdaniem nie sięgała tak wysoko, jak opisywał autor ${ }^{43}$.

Pracę nad syntetycznym ujęciem historii narodów słowiańskich Bidlo uważał także w kolejnych latach za jedno ze swoich najważniejszych zadań. W 1928 roku ogłosił monografię pt. Déjiny Slovanstva [Dzieje Słowiańszczyzny]. Dwa akapity poświęcił w niej również problematyce ruchu nowosłowiańskiego. Tym razem podkreślał zbieg okoliczności (60. rocznica Zjazdu Słowiańskiego 1848 r.) zamiast ogólniejszej potrzeby jego zwołania. Najważniejszą rolę w rokowaniach, jego zdaniem, odgrywały próby złagodzenia stosunku polsko-rosyjskiego oraz serbsko-bułgarskie pertraktacje dotyczące Macedonii, lecz tylko ostatnio wymienione zaowocowały pewnymi rezultatami ${ }^{44}$.

40 A. Černý [rec.], Slovanstvo, „Slovanský přehled” 1912, t. 14, s. 226-230, 276-279.

41 „Jazykové a národopisné rozdíly mezi Velikorusy a Malorusy sice nejsou tak hluboké, aby je nebylo možno překlenouti, ale historický vývoj a docela různé tradice jsou př́činou, že Malorusové chtějí býti zvláštní individualitou národní. Komu podaří se odvrátiti tento četný národ (22 milionů) od této «neštastné» snahy? Není spíše povinností vážných politiků počítati s tím jako s nezměnitelným faktem a na tomto podkladě zaříditi své jednání, než potlačováním maloruského separatismu jej sesilovati a kopati ještě hlubší propast mezi oběma ruskými národnostmi?" J. Bidlo, Historický vývoj Slovanstva, s. 228.

42 A. Černý [rec.], Slovanstvo, s. 230.

43 Ibidem, s. 277.

44 J. Bidlo, Dějiny Slovanstva, Praha 1928, s. 225. 


\section{ZAKOŃCZENIE. W POSZUKIWANIU SYNTEZY DZIEJÓW EUROPY ŚRODKOWOWSCHODNIEJ}

Z recenzji monografii Slovanstvo wyraźnie widać, że Bidlo przy pisaniu tekstu stąpał po kruchym lodzie i w wielu przypadkach wystawiał się na krytykę z bardzo różnych stron. W ostateczności mógł być więc zadowolony, ponieważ jego starania o jak największą bezstronność oraz fachowe podejście do problematyki mniej więcej oceniono pozytywnie. $Z$ dzisiejszego punktu widzenia można skonstatować, że w czeskiej historiografii do lat 30 . XX wieku nie zaprezentowano innej, bardziej przekonującej, koncepcji syntetycznego ujęcia dziejów Słowiańszczyzny od czasów najstarszych do początku XX wieku. Kwestia ta została poruszona również w skali międzynarodowej podczas obrad Międzynarodowego Kongresu Historycznego w Warszawie w 1933 roku i na samym początku ciekawej dyskusji, w której wzięli udział między innymi Oskar Halecki oraz Marceli Handelsman, poruszony był referat - Jaroslava Bidlo właśnie. Późniejsza dyskusja toczyła się dalej na łamach czasopism ${ }^{45}$.

Na zakończenie można skonstatować, że udział bohatera niniejszej rozprawy w ruchu neosłowiańskim polegał przede wszystkim na skupieniu się na sprawach naukowych, mianowicie autor Slovanstva ograniczał się do redagowania publikacji zbiorowej, do której sam napisał jeden z podstawowych rozdziałów. Bidlo, który w okresie między zjazdem neosłowiańskim a wydaniem omawianej publikacji uzyskał tytuł profesora zwyczajnego, skorzystał z okazji, żeby położyć podwaliny pod jedno ze swoich największych osiągnięć naukowych. Chociaż jego poglądów na charakter dziejów Słowiańszczyzny i Europy Wschodniej oraz ich periodyzację nie przyjęto bez zaprzeczeń, przyczynił się do bardzo ważnej dyskusji, trwającej w pewien sposób do dzisiaj i nieograniczającej się tylko do środowiska historycznego.

\section{BIBLIOGRAFIA}

-a 1 [rec.], Slovanstvo, „Věstník českých profesorư”, II 1912, t. 19, nr 6, s. 183-184.

Batow ski H., Neoslawizm a stosunki polsko-rosyjskie i polsko-czeskie (1908-1914) [w:] Z polskich studiów slawistycznych, seria 3. Historia. Prace na VI Międzynarodowy Kongres Slawistów w Pradze 1968, Warszawa 1968, s. 236-245.

Bidlo J., Dějiny Slovanstva, Praha 1928.

Bidlo J., O historii Slovanstva jako celku, „Český časopis historický” 1911, t. 17, s. 143-151. Bidlo J., Positivni výsledek pražského sjezdu novoslovanského r. 1908, „Národní listy”, 31 XII 1911, nr 360, príloha „Z kulturního života”, s. 1.

Bouček J., Jan Slavík. Př́běh zakázaného historika, Praha 2002.

45 D. Mishkova, Spatial Assymetries: Regionalist Intellectual Projects in East Central Europe in Interwar Period [w:] Decentering European Intellectual Space, eds. M. Jalava, S. Nygård, J. Strang, Leiden-Boston 2018, European Studies, vol. 35, s. 157-160. 
Černý A., Po slovanských dnech v Petrohradě a Varšavě, „Slovanský přehled” 1908, t. 10, s. 7-15, 61-69.

Černý A., Slovanské sjezdy r. 1908, „Slovanský přehled” 1909, t. 11, s. 7-15, 61-69.

Černý A. [rec.], Slovanstvo, „Slovanský přehled” 1912, t. 14, s. 226-230, 276-279.

Doubek V., T. G. Masaryk a česká slovanská politika, Praha 1999.

Ďurčanský M., Historyk Jaroslav Bidlo (1868-1837) - tącznik między krakowska szkoła historyczna i czeska szkoła historyczna Jaroslava Golla (1846-1929) [w:] Krakowska szkoła historyczna a Polskie Towarzystwo Historyczne. Studia historiograficzne, red. P. Biliński, P. Plichta, Warszawa-Kraków 2017, s. 47-59.

Giza A., Neoslawizm i Polacy 1906-1910, Szczecin 1984.

Hadler F., ,...nevertheless, a great theatrical exhibition of Slav Solidarity.” Der Prager Slawen-Kongress von 1908 als Hauptaktion des Neoslawismus [w:] Approaches to Slavic Unity. Austro-Slavism, Pan-Slavism, Neo-Slavism and Solidarity Among the Slavs Today, red. K.A. Makowski, F. Hadler, Poznań 2013, s. 131-151.

Jaworski R., Die polnische und die tschechische Variante des Neoslawismus [w:] Polen und die böhmischen Länder im 19. und 20. Jahrhundert. Politik und Gesellschaft im Vergleich. Vorträge der Tagung des Collegium Carolinum in Bad Wiessee vom 15. bis 17. November 1991, hrsg. P. Heumos, München 1997, s. 43-55.

Jaroslav Bidlo - Milada Paulová. Střet generací? Paměti a vzájemná korespondence zakladatelu české byzantologie a slovanských studií, red. D. Brádlerová, J. Hálek, Praha 2014.

Jednání I. prípravného slovanského sjezdu v Praze 1908, Praha 1910.

Korespondencja Feliksa Konecznego z Jaroslavem Bidlo, wyd. P. Biliński, M. Ďurčanský, „Biuletyn Biblioteki Jagiellońskiej” 2016, t. 66, s. 45-68.

Korespondencja Władysława Semkowicza i Jaroslava Bidlo. Kartka z historii stosunków naukowych polsko-czeskich w okresie międzywojennym, oprac. M. Ďurčanský, „Krakowski Rocznik Archiwalny” 2012, t. 18, s. 131-154.

Poláci v Čechách v době povstání listopadového a ,velké emigrace, „Slovanský přehled” 1930, t. 22, s. 504-509, 583-598, 670-678, 721-741.

Krejčí K., První krise českého slovanství. Vliv polského povstání listopadového na české národni obrození, „Slovanský přehled” 1928, t. 20, s. 13-22, 108-122, 177-201, 249-272.

Lustigová M., Karel Kramár. První československý premiér, Praha 2007.

Macůrek J., Dějepisectvi evropského východu, Praha 1946.

Mishkova D., Spatial Assymetries: Regionalist Intellectual Projects in East Central Europe in Interwar Period [w:] Decentering European Intellectual Space, eds. M. Jalava, S. Nygård, J. Strang, Leiden-Boston 2018, European Studies, vol. 35, s. 143-164.

Opacki Z., W kręgu Polski, Rosji i Słowiańszczyzny. Myśl i działalność społeczno-polityczna Mariana Zdziechowskiego do 1914 r., Gdańsk 1996.

Pakosta F., [rec.], Slovanstvo, „Naše doba” 1912, nr 19, s. 699-700.

Slavík J. [rec.:] Slovanstvo, „Český časopis historický” 1912, t. 18, s. 341-344.

Slovanstvo. Obraz jeho minulosti a prítomnosti, red. J. Bidlo, J. Polívka, Praha 1912.

Vlček R., Nacionalismus, panslavismus a neoslavismus - pokusy o řě́eni krize ruského impéria na přelomu 19. a 20. století?, „Slovanský přehled” 1994, t. 80, s. 1-17.

Vlček R., Ruský panslavismus - realita a fikce, Praha 2002.

Vyšný P., Neo-Slavism and the Czechs 1898-1914, Cambridge [et al.] 1977.

Žáček V., Ohlas polského povstání 1863 v Čechách, Praha 1935. 